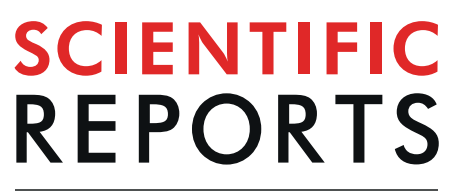

natureresearch

\title{
OPEN
}

Published online: 04 February 2020

\section{Author Correction: Systematic assessment of prescribed medications and short-term risk of myocardial infarction - a pharmacopeia-wide association study from Norway and Sweden}

Abhijit Sen, loannis Vardaxis, Bo Henry Lindqvist, Ben Michael Brumpton, Linn Beate Strand, Inger Johanne Bakken (D), Lars Johan Vatten, Pål Richard Romundstad, Rickard Ljung, Kenneth Jay Mukamal \& Imre Janszky

Correction to: Scientific Reports https://doi.org/10.1038/s41598-019-44641-1, published online 4 June 2019

In the Supplementary Information file originally published with this Article, Appendix A was omitted. This error has been corrected in the Supplementary Information that now accompanies the Article.

(c) (1) Open Access This article is licensed under a Creative Commons Attribution 4.0 International License, which permits use, sharing, adaptation, distribution and reproduction in any medium or format, as long as you give appropriate credit to the original author(s) and the source, provide a link to the Creative Commons license, and indicate if changes were made. The images or other third party material in this article are included in the article's Creative Commons license, unless indicated otherwise in a credit line to the material. If material is not included in the article's Creative Commons license and your intended use is not permitted by statutory regulation or exceeds the permitted use, you will need to obtain permission directly from the copyright holder. To view a copy of this license, visit http://creativecommons.org/licenses/by/4.0/.

(C) The Author(s) 2020 